\section{University of New Hampshire}

Carsey School of Public Policy

\section{CARSEY RESEARCH}

National Fact Sheet \#35

Winter 2017

\title{
Public Support for Environmental Protection
}

\author{
Lawrence C. Hamilton
}

$\mathrm{T}$

The U.S. Environmental Protection Agency

(EPA), charged with protecting human health

and the environment through regulations based

on laws passed by Congress, was proposed and signed

by Republican President Richard Nixon in 1970. Other landmark environmental legislation of the 1960s, 70s, and 80 s that enjoyed bipartisan support includes the Endangered Species Act (1973), the Clean Water Act (1977), and the Clean Air Act (1963, expanded in 1970, 1977, and 1990). These laws and others were advanced by Democratic and Republican administrations alike.

More recently, however, partisan divisions on environmental protection have widened, with Republican leaders frequently in opposition. ${ }^{1}$ This opposition took a strong form in the 2016 presidential campaign, when Republican Donald Trump called for abolishing the EPA and eliminating many environmental regulations. After taking office he seemed to moderate his position on abolishing the EPA, but he nominated as director someone who has sued the agency to halt its enforcement activities. In Congress, some Republicans have introduced bills to terminate the EPA, or restrict its capabilities for monitoring, enforcement, and research.

Does public opinion now mirror the stark partyline divisions among political leaders? To find out, we placed a question on the Granite State Poll, a quarterly random-sample telephone survey. Although this poll focuses on New Hampshire residents, previous studies have found that their responses to environmental questions often resemble those on nationwide surveys. ${ }^{2}$ For this particular poll, interviews with 505 people took place between January 31 and February 8, 2017. ${ }^{3}$

During his presidential campaign, Donald Trump called for abolishing the Environmental Protection Agency, and eliminating or reducing many U.S. environmental rules. Do you agree that environmental protection rules generally should be reduced? Or do you think that environmental protections instead should be strengthened? Or left as they are?

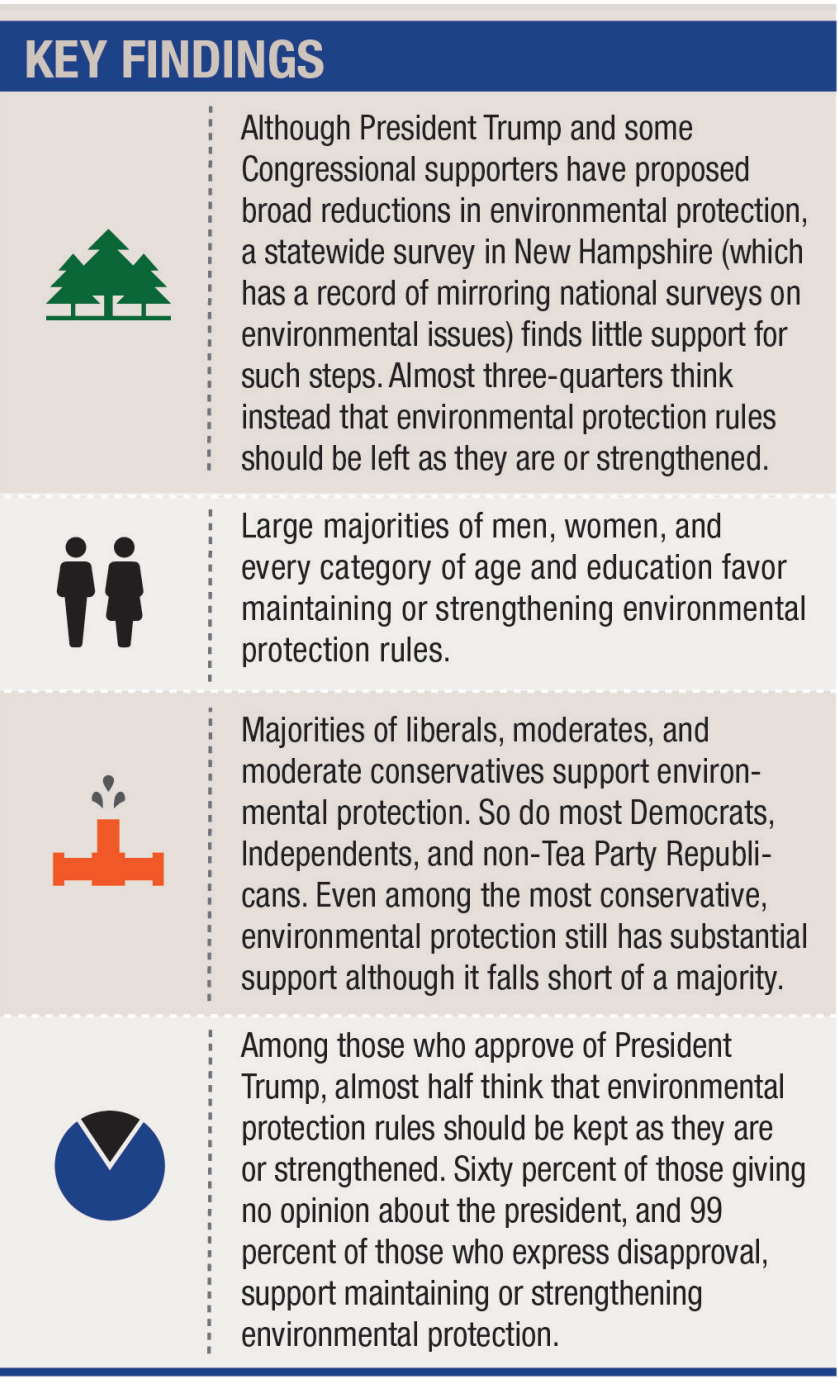

Figure 1 charts the responses. Only 20 percent of the survey respondents favor such reductions. Twenty-four percent prefer things as they are, while 49 percent say environmental protections should actually be made stronger. Thus, the political drive to reduce environmental protection appears to have little backing among the general public. 


\section{FIGURE 1. SHOULD ENVIRONMENTAL RULES BE REDUCED, STRENGTHENED, OR LEFT AS THEY ARE?}

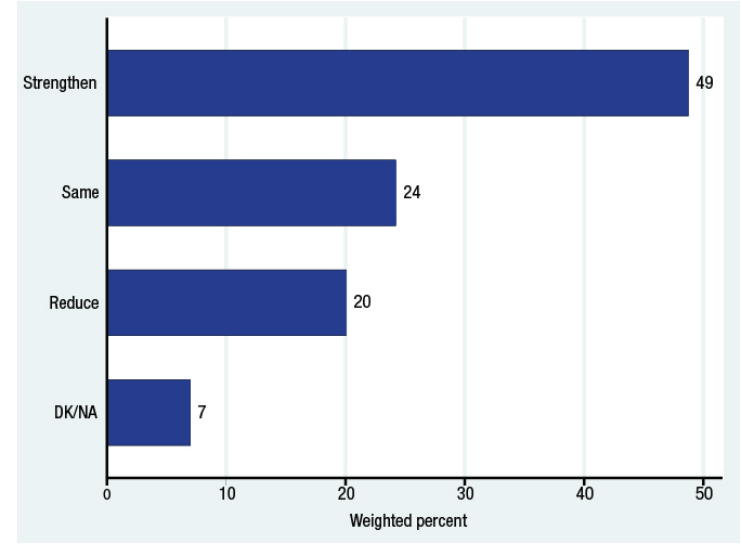

Source: Granite State Poll, February 2017

But who holds these different views? Figure 2 breaks responses down by age, gender, education, and politics. All age groups favor maintaining or strengthening environmental protection; this sentiment is strongest (81 to 84 percent) among younger adults age 18 to 39. Majorities of both men and women, but significantly more women (82 vs. 63 percent), support environmental protection. There are modest, nonsignificant differences by education: support for environmental protection is somewhat lower among those with a high school education or less, although it is still a substantial majority (68 percent) even in that group. Political differences, on the other hand, are wide. Very large majorities (85 to 96 percent) of self-identified liberals and moderates, and of Democrats and Independents, say that environmental rules should be kept the same or made stronger. Majorities (59 to 62 percent) of moderate conservatives and non-Tea Party Republicans also hold this view. Only among respondents who self-identify as most conservative, or as Tea Party supporters, does support for environmental protection fall short of a majority (33 to 40 percent).

Overall, 43 percent of the respondents on this survey say they approve, and 48 percent disapprove, of the way Donald Trump is handling his job as president ( 9 percent express no opinion). Among those who approve of President Trump, almost half think that environmental protection rules should be kept as they are or strengthened. Sixty percent of those giving no opinion about the president, and 99 percent of those who express disapproval, support maintaining or strengthening environmental protection. Environmental issues received relatively little attention during the campaign, but a disjunction between public opinion and political leadership could become more salient now that the election is past, as policy choices come into focus.

\section{FIGURE 2. ENVIRONMENTAL RULES SHOULD BE MAINTAINED OR STRENGTHENED, BY RESPONDENT AGE, SEX, EDUCATION, IDEOLOGY, PARTY, AND APPROVAL OF PRESIDENT TRUMP}

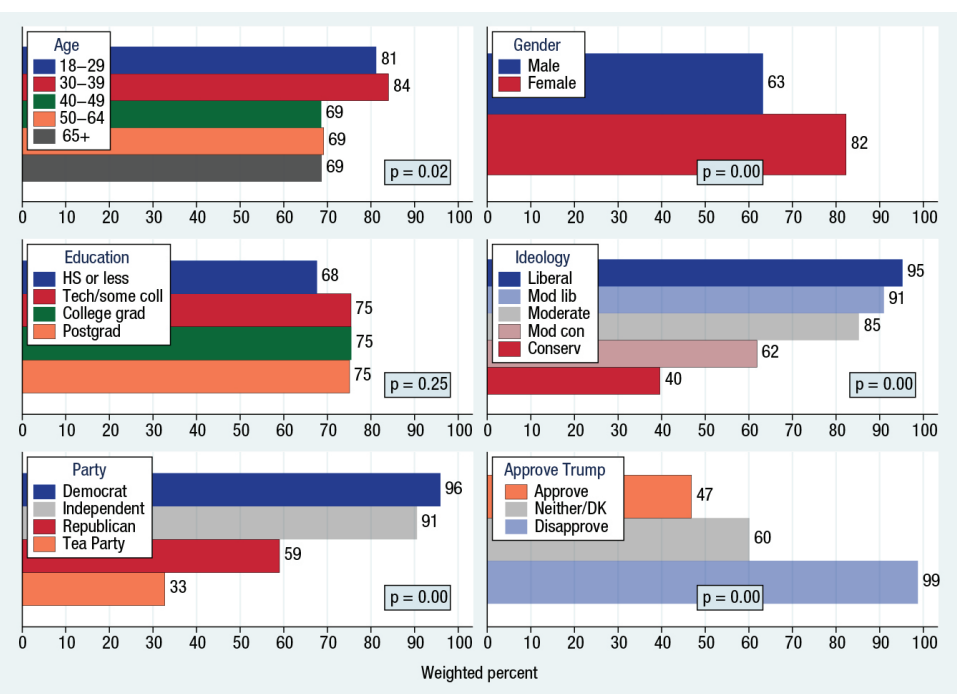

Source: Granite State Poll, February 2017

\section{Endnotes}

1. R.E. Dunlap and A.M. McCright, "A Widening Gap: Republican and Democratic Views on Climate Change," Environment Sep/Oct (2008), http://www. environmentmagazine.org/archives/back\%20issues/ september-october\%202008/dunlap-full.html

2. For example, see L.C. Hamilton, "Where Is the North Pole? An Election-Year Survey on Global Change" (Durham, NH: Carsey School of Public Policy, University of New Hampshire, 2016), http://scholars.unh.edu/carsey/285/; L.C. Hamilton, "Public Awareness of the Scientific Consensus on Climate," Sage Open (2016), doi: 10.1177/2158244016676296; L.C. Hamilton, "Did the Arctic Ice Recover? Demographics of True and False Climate Facts," Weather, Climate, and Society (2012), 4(4):236-249, doi: 10.1175/WCAS-D-12-00008.1.

3. The Granite State Poll is conducted by the Survey Center at the University of New Hampshire. For this winter 2017 poll, the response rate was 25 percent.

\section{About the Author}

Lawrence C. Hamilton is professor of sociology and a senior fellow at the Carsey School of Public Policy at the University of New Hampshire (https://carsey.unh. edu/person/lawrence-hamilton).

\section{A cknow ledgments}

Support for the environmental and science questions on the Granite State Poll was provided by a grant from the National Science Foundation (New Hampshire EPSCoR EPS-1101245). Any opinions, findings, and conclusions or recommendations expressed in this material are those of the author and do not necessarily reflect the views of the National Science Foundation. 